\title{
SECOND LANGUAGE ACQUISITION IN BILINGUAL CHILDREN: CASE OF IMMIGRANTS
}

\author{
ОПАНУВАННЯ ДРУГОЇ МОВИ ДІТЬМИ-БІЛІНГВАМИ: \\ НА ПРИКЛАДІ ІММІГРАНТІВ
}

\author{
Devitska A.I. \\ orcid.org/0000-0002-7575-5390 \\ Candidate of Philological Sciences, \\ Associate Professor at the Department of Theory and Practice of Translation \\ Uzhhorod National University
}

The present study explores the second language acquisition in Slovak immigrant workers' bilingual children from psycholinguistic and sociolinguistic perspective. It explains an acculturation as the process of mastering the knowledge and skills necessary for living in a foreign culture and distinguishes its four strategies. The concept of the second language acquisition is interpreted as the product of a subconscious process very similar to the process children undergo when they acquire their first language. It requires meaningful interaction in the target language - natural communication - in which speakers are concentrated not in the form of their utterances, but in the communicative act.

The paper has argued that enculturation is a process that allows Slovak immigrant workers' children to master a whole system of cultural norms, a system of value orientations and preferences accepted in society; etiquette norms of behavior in different life situations; generally accepted approaches to the interpretation of various phenomena and events; the foundations of the socio-political structure of this society; national traditions, customs; the prevailing morality, as well as worldview; the prevailing fashion, styles, symbols, regalia; national authorities; political and cultural history of the society and main symbols of national dignity, pride.

The review includes the question of factors which may contribute to speech interference in English spoken by Slovak immigrant workers and their children, namely personal problems and program factors. The paper demonstrates that another significant aspect for Slovak immigrant workers' children is the process of awareness of immigrants' ethnic identity therefore, it takes place in different ways, both at the level of individuals and in different situations of interaction, for example, whether they live in a multi-ethnic or mono-ethnic environment. The article also analyzes how minority-language influences on second language acquisition by Slovak immigrant workers' children.

Key words: second language acquisition, labour immigration, bilingual children, assimilation, separation, marginalization, integration.

У статті проаналізовано процес опанування другої мови дітьми-білінгвами на прикладі іммігрантів з психолінгвістичної та соціолінгвістичної точки зору. Водночас пояснено поняття «акультурації» як процес оволодіння знаннями та вміннями, які необхідні для проживання в іноземному соціокультурному середовищі, зокрема виділено чотири стратегії акультуації. Поняття опанування другої мови трактується як підсвідомий процес, який є схожим на процес опанування рідної мови дітьми. Цей процес включає змістовну взаємодію під час іншомовної комунікації, в якій мовці зосереджені не на формі своїх висловлювань, а власне на комунікації.

У статті підкреслено, що інкультурація - це процес, який дозволяє дітям словаків-іммігрантів опановувати цілу систему культурних норм, ціннісних орієнтацій та уподобань, прийнятих в іншомовному суспільстві; етикетні правила поведінки в різних життєвих ситуаціях; загальновизнані підходи до трактування різних явищ та подій; основи суспільно-політичної структури цього суспільства; національні традиції, звичаї; мораль, світогляд; стилі, символи, реалії; національні органи влади; політичну та культурну історію суспільства та основні символи національної гідності та гордості.

Схарактеризовано фактори, які можуть здійснювати вплив на мовну інтерференцію в англійському мовленні словаків-іммігрантів та їх дітей, зокрема особисті проблеми та програмні фрактори. У статті зазначено про такий важливий аспект для дітей словацьких іммігрантів, як процес усвідомлення етнічної ідентичності іммігрантів, який реалізується по-різному і залежить від багатоетнічного чи моноетнічного середовища. У праці також окреслено вплив рідної мови на процес опанування другої мови дітьми-білінгвами із сімей трудової імміграції.

Ключові слова: опанування другої мови, діти-білінгви, трудова імміграція, діти-білінгви, асиміляція, сепарація, маргіналізація, інтеграція.

Introduction. After years of bilingualism studies, all the facts indicate that it has a positive effect on personality development, regardless of age. That is why educators in many countries emphasize the need to implement a policy of bilingualism in education. The facts show that the governments of most countries are pursuing a policy of monolingualism. Therefore, only $25 \%$ of nearly 200 countries recognize two or three official languages. But despite such a conservative government policy, more and more children are receiving education in several languages, and their numbers are already outnumbered by those who learn only one mother tongue. Pedagogical sources use the terms "bilingual learning" and "bilingual 
education", traditionally considering education as a process and a process result.

Today, bilingual learning is a means of gaining bilingual education and the process of forming a personality open to interaction with the outside world. Since, in the process of bilingual learning, foreign language is considered not only as a means of daily communication, but also as a tool for cognition of the world, special knowledge, they as a result achieve a high integrative level of linguistic and subject competence [3, p. 32]. Bilingual learning contributes to broadening the students' worldview through comparative analysis of foreign language cultures, forming a tolerant attitude towards alternative views related to the national specificities of different peoples as well as stimulates the need for further education and self-development, which is a prerequisite for professional activity in the modern world. However, achieving these goals is only possible if the right model of bilingual learning is chosen, which should take into account the needs and capabilities of not only society but also students.

Recent Research Analysis. In recent years, the second language acquisition has become a question of great interest in a wide range of fields. Sociolinguistic and sociophonetic works have appeared that describe the second language acquisition of representatives of various age, as well as territorial and gender groups (J. Cummins, B. Jansen, J. Lalleman, P. Muysken, S. Krashen, M. Long, B. Taylor). The focus of modern linguistic research is directed to the study of the role of an acculturation model for the second-language acquisition (R. Scarcella, J. Schumann, S. Krashen, S. G. Herrera, K.G. Murry). A review of theoretical and experimental studies has led to the conclusion that the concept of second language acquisition is to be interpreted as the product of a subconscious process. According to $\mathrm{S}$. Krashen it is very similar to the process children undergo when they acquire their first language. It requires meaningful interaction in the target language - natural communication in which speakers are concentrated not in the form of their utterances, but in the communicative act [8].

Topicality. Current process of international globalization and integration make the research of ethnic and cultural specifics of bilingual immigrants as firstrate. The studies of intercultural communication today are represented in the scientific works of J. C. Richards, T.S. Rodgers, B. F. Skinner, M. J. Traxler.

In terms of learning the second language acquisition in Slovak immigrant workers' bilingual children one should consider psycholinguistic and sociolinguistic aspects, which are of high importance. From the psycholinguistic point of view a bilingual child who acquires the second language becomes an object of study, that means that level of intelligence, age, type of cognition as well as ways of mastering the second language are taken into account. In contrast, the studies on sociolinguistic aspects of second language acquisition in bilingual children focus on socio and socio-psychological aspects that have a strong impact on the ways of mastering the second language.

It has commonly been assumed that, intercultural contacts depend on the ability of the participants to understand each other and reach an agreement $[6 ; 7]$. Those factors are defined mostly by ethnic culture of each part that interacts as well as nations' psychological and cultural values they possess. Therefore, intercultural communication can be observed as native speakers' contact, which results speech interference on different levels. Thus, mainly phonetic interference causes difficulty in perception and production of bilinguals' speech.

In terms of intercultural communication there appears an interaction between language maps of the world as well as their part which is national specific one. We consider intercultural communication as the interaction of different cultures, that is conceptualized by different language systems. Finally, intercultural communication is as interaction of national specific part of language maps of the world, in which the citizens share mutual socio-cultural space.

Modern transformational processes in the countries of European Union have contributed to the demand for information on the culture, the strengthening of the communicative positions of English and other European languages, mainly because of rapid labour immigration increase. Thus, bilingual children from Slovak immigrant families have to cope with dynamic adaptation to the joint functioning of the Slovak and English languages in their cognition.

Particular attention should be paid to empathy the ability to understand other people, their thoughts as well as feelings, especially in second language acquisition. Personality as a subject of communication becomes real and effective only when the community has a developed reflection - the ability to perceive oneself as a self-enhancing personality. The most important component of a communicative culture of intercultural communication is language mastering.

The expediency and principles of using multiple languages in education can be influenced by many factors, such as the linguistic diversity of a country or region, particular social and religious sentiment, or the desire to maintain one's cultural identity. The 
latest language education programs are often aimed at developing skills in languages of international communication, combining them with their mother tongue [6]. The overall portrait of a foreign language education and learning policy in two or more languages is quite complex but at the same time amazing.

Bilingual linguistic behavior is seen as the process of choosing an option for constructing a socially correct expression, so aspects of language are perceived as socially conditioned variation in language. Therefore, scientists are trying to identify mechanisms for selecting socially relevant options, establish selection criteria as well as to find out social factors that influence the choice of variant.

The purpose of socio-linguistic analysis is to identify the social norms that determine the linguistic behavior of speakers. The main social components of bilingual linguistic behavior according to A. Schweitzer are referred to social roles, social statuses, orientation to certain social values and norms [2, p. 40]. However, the researcher E. Vereshchagin believes that when analyzing behavior, it is obligatory to pay attention to the environment in which the communication occurs, whereas the choice of the topic, the use of familiar comparisons, hints, ways to support communication and non-verbal communication are important as well [1, p. 22].

It is necessary here to clarify exactly what is meant by the term "adaptation". Actually, adaptation means adaptation to changing conditions, to a new environment [9, p. 50]. If this definition is applied to Slovak immigrant workers' children, then a new environment for them will be a host culture (that is British one) and new social conditions, typical for Great Britain. Therefore, in relation to Slovak immigrant workers and their children the term socio-cultural adaptation can be safely used. If immigrants consider themselves to be of another ethnicity, then a large sector of ethno-confessional adaptation is added to socio-cultural adaptation as a whole. Moreover, in our case, we have labor immigrants, thus, we add one more adaptation, that is professional.

In terms of our research, acculturation is of high importance. The term is usually used to describe the process of mastering a foreign culture as a whole. It is assumed that the basis of this process is the interaction of two cultures (foreign and native) [4, p. 11]. As applied to different social groups, the term acculturation has been used to refer to situations in which we describe the directions of change in the original cultural models of interacting groups [3, p. 42]. At the level of an individual, a Slovak immigrant worker's child, an acculturation is understood as the process of mastering the knowledge and skills necessary for living in a foreign culture. Thus, acculturation strategies include the direction vectors of changes in the initial cultural models of both groups and individuals [4].

In our research four strategies of acculturation are distinguished:

1) assimilation is a situation when Slovak immigrant workers and their children fully accept the values and norms of a different culture, while abandoning their own norms and values;

2) separation is a situation of denial of a foreign (English in our case) culture while maintaining a native one (other names - isolation, autonomy);

3) marginalization is a loss of connection with Slovak immigrant workers' and their children' own culture as well as lack of connection with the majority culture (this situation often arises due to discrimination);

4) integration is a process of maintaining a connection with the old culture and having a connection with a new one.

Therefore, the result of acculturation is a longterm adaptation to life in a foreign culture, including socio-cultural adaptation, the ability to navigate freely in a new culture and society, to solve everyday problems within the family, at home, at work, during studies; psychological comprises well-being, good mental health as well as psychological satisfaction; economic one, that includes satisfaction with work, level of immigrants' professional achievements, immigrants' well-being in the new culture (it should be noted that this type of adaptation result has been discussed relatively recently).

While a variety of definitions of the term "enculturation" have been suggested, this paper will use the definition suggested by J. Berry, who saw it as the mastery of a person in the process of socialization of the norms of his own culture, but can, if desired, be used to describe the development of another culture [5, p. 12].

In both cases, when talking about enculturation, they try to focus on training. This emphasis is also reflected in the definitions of enculturation, as the following examples of definitions illustrate well. Enculturation is a gradual development of skills, manners, and behavioral norms by a person that are characteristic of a certain type of culture [5, p. 13]. Enculturation is a long and gradual development by a person of methods, norms, practical recommendations in everyday life as well as the formation of cultural competence in relation to the standards of the society in which a person lives. 
Research material. The participants in our linguistic research include both the Slovak immigrant workers and their children, who immigrated to the United Kingdom (Birmingham) and have lived there from 15 to 25 years. The principal aim of the research was to find out the ways of acculturation, adaptation while acquiring a second language and how minority-language influences on second language acquisition by Slovak immigrant workers' children. Furthermore, the research aimed at focusing on the second language acquisition process, mainly on minority language skills on second language acquisition (that is Slovak language influence on English speech of Slovak immigrant workers' children). The age of the Slovak immigrant workers' children varied from 6 to 15. All the Slovak immigrant workers agreed to participate in the research.

Conclusions. Mainly, enculturation is a process that allows Slovak immigrant workers' children to master a whole system of cultural norms, a system of value orientations and preferences accepted in society; etiquette norms of behavior in different life situations; generally accepted approaches to the interpretation of various phenomena and events; the foundations of the socio-political structure of this society; national traditions, customs; the prevailing morality, as well as worldview; the prevailing fashion, styles, symbols, regalia; national authorities; political and cultural history of the society and main symbols of national dignity, pride, etc.

Among the psychological mechanisms, or rather, adaptation tools, there appear two fundamentally different processes: imitation and identification (acceptance by Slovak immigrant workers' children). The first process is more appropriate for temporary Slovak immigrant workers' children, the second one is for those who adapt for a long time to a new culture. Concluding the description of the acculturation process in Slovak immigrant workers' children in the United Kingdom, it should be noted that reaching agreement on understanding of commonly used terms and describing the mechanisms of sociocultural adaptation is a necessary but not sufficient condition for an effective dialogue. In order for this dialogue to really contribute to improving the adaptation of Slovak immigrant workers' children, it is also necessary to agree on a current number of problems arising in connection with immigration flows.

Therefore, the range of these problems is wide: from the legal status of immigrants to their psychological comfort. Among the most acute problems we would attribute intolerance and its prevention (in particular, in United Kingdom); legal and economic factors of intercultural communication; prospects for enculturing children from immigrant families (both for their native and host cultures).

Admittedly, the question of factors which may contribute to speech interference in English spoken by Slovak immigrant workers and their children includes the following:

1) personal problems (including low level of self-esteem in combination with no progress in English, family problems as well as lack of support for family culture, age of the immigrants, temporal factor of language learning and daily stress);

2) program factors (namely, lack of ability to succeed in another country and imperfect system for gradual adaptation / integration into a foreign-language culture and society).

Another significant aspect for Slovak immigrant workers' children is the process of awareness of immigrants' ethnic identity therefore, it takes place in different ways, both at the level of individuals and in different situations of interaction, for example, whether they live in a multi-ethnic or mono-ethnic environment. It is obvious, that the multi-ethnic environment develops much faster and gives the individual more opportunities to acquire knowledge about the characteristics and differences of his ethnic group from other groups as well as forms and develops intercultural interaction skills.

Thus, ethnic awareness is formed earlier, ethnic identity is more clearly recognized if socialization took place in a multi-ethnic environment (for example, in United Kingdom). In individuals living in a multi-ethnic environment, ethnic identity is more vivid and represented whereas among individuals living among culturally similar groups, awareness of their own ethnicity does not become a vital problem. Moving on now to consider the features of the formation of ethnic identity, it should be noted that they also depend on which group the individual belongs to, whether the group of the majority or minority one. Likewise, Slovak immigrant workers' children of minority groups tend to identify with the dominant group, which reflects the early awareness of children about the existence of a certain social structure, that in society some groups are rated higher than others. But with age and the development of ethnic identity, members of ethnic minorities usually experience a shift to intergroup orientation. 
REFERENCES:

1. Верещагин Е.М. Психологическая и методическая характеристика двуязычия (билингвизма). Москва : Изд-во Моск. ун-та, 1969. 53 с.

2. Швейцер А.Д. К проблеме социальной дифференциации языка. Вопросы языкознания. Москва : Наука, 1982. № 5. С. 39-48.

3. Appel, R. Immigrant children learning Dutch: sociolinguistic and psycholinguistic aspects of second-language acquisition. Dordrecht, the Netherlands: Foris, 1984. Pp. 198.

4. Berry J. W. Acculturation as Varieties of Adaptation. A. Padilla (ed.), Acculturation: Theory, Models and Some New Findings. Boulder: West-view, 1980. P. 9-25.

5. Berry J. W. Conceptual Approaches to Acculturation. In K. Chun, P. Balls-Organista, G. Marin (eds.), Acculturation: Advances in Theory, Measurement and Applied Research. Washington: APA Books, 2003. P. 17-37.

6. Brislin R.W., Cushner K., Cherrie C., Yong M. Intercultural interactions: A practical guide. Beverly Hills, CA : Sage, 1986, Pp. 384.

7. Jansen, B., Lalleman, J., \& Muysken, P. The alternation hypothesis: Acquisition of Dutch word order by Turkish and Moroccan foreign workers, 1981, Pp. 115.

8. Krashen, S., Long, M., \& Scarcella, R. Age, rate and eventual attainment in second language acquisition. TESOL Quarterly, 13, 1979, P. 573-582.

9. Redfield R., Linton R., Herskovits M. J. Memorandum for the study of acculturation. American Anthropologist, 1936, V. 38. P. $149-152$. 